\title{
FAKTOR-FAKTOR KEBERHASILAN BERWIRAUSAHATANI (AGRIBISNIS): SEBUAH STUDI LITERATUR
}

\author{
ENTREPRENEURSHIP SUCCESS FACTORS: A LITERATURE REVIEW \\ DINDIN MUADIN*, LIDYA NUR AMALIA, ZULFIKAR NOORMANYSAH \\ Program Studi Agribisnis, Program Pascasarjana, Universitas Siliwangi \\ *E-mail: muadind@gmail.com
}

\begin{abstract}
ABSTRAK
Kewirausahaan merupakan salah satu faktor yang dapat meningkatkan pertumbuhan ekonomi suatu negara. Keberhasilan dalam wirausaha ditentukan oleh beberapa faktor. Penelitian ini dilaksanakan dengan tujuan untuk mengetahui faktor-faktor yang menentukan keberhasilan wirausaha. Penelitian dilaksanakan dengan metode studi literatur menggunakan artikel jurnal yang membahas mengenai wirausaha. Hasil penelitian menunjukkan bahwa kesuksesan setiap pelaku usaha tergantung pada perilakunya dalam menjalankan sebuah usaha, latar belakang pendidikan, dan budaya masyarakat secara umum. Kesuksesan wirausaha juga ditentukan oleh konsistensi dalam menjalankan usaha, sungguh-sungguh, memahami keinginan pasar, memperkuat pengetahuan tentang manajemen usaha, selalu mengikuti perkembangan teknologi informasi, dan mampu beradaptasi dengan lingkungan yang dinamis.
\end{abstract}

Kata Kunci: keberhasilan, wirausaha, agribisnis, faktor-faktor

\begin{abstract}
Entrepreneurship is one of the factors that can increase a country's economic growth. Success in entrepreneurship is determined by several factors. This research was conducted with the aim of knowing the factors that determine entrepreneurial success. The research was carried out with the literature study method using journal articles that discuss entrepreneurship. The results showed that the success of each business actor depends on his behavior in running a business, educational background, and the culture of the community in general. Entrepreneurial success is also determined by consistency in running a business, really, understanding market wants, strengthening knowledge about business management, always keeping abreast of information technology developments, and being able to adapt to dynamic environments.
\end{abstract}

Keywords: success, entrepreneurship, agribusiness, factors

\section{PENDAHULUAN}

Negara Indonesia merupakan negara

yang tergolong ke dalam negara berkembang. Salah satu indikator negara berkembang dapat dilihat dari pertumbuhan ekonomi negara tersebut. Perkembangan ekonomi dapat menurun apabila banyaknya jumlah pengangguran. Salah satu cara untuk membantu perekonomian Indonesia yaitu dengan meningkatkan jiwa wirausaha pada masyarakat Indonesia. Lestari (2019) menjelaskan bahwa tanda dari negara maju yaitu banyaknya masyarakat terdidik dan merasakan bahwa dunia wirausaha merupakan sektor yang penting.

Kewirausahaan merupakan salah satu faktor yang dapat meningkatkan 
pertumbuhan ekonomi suatu negara. Dampak positif lain dari kewirausahaan yaitu dapat meningkatkan kemampuan, kreativitas, dan produktifitas. Kewirausahaan juga dapat meningkatkan devisa negara, sehingga dapat menarik investor untuk berinvestasi apabila usaha tersebut berjalan dengan lancar (Putra, 2018). Wirausaha dapat dikatakan sebagai aset bangsa untuk meningkatkan ekonomi negara. Wirausaha juga disebut sebagai agen perubahan karena pengusaha dituntut untuk selalu berinovasi (Pamela et al, 2016).

Wirausaha dapat berhasil maupun tidak berhasil, hal tersebut dipengaruhi oleh keterampilan pengusaha itu sendiri. Pengusaha harus dapat melihat kesempatan dan peluang dengan tepat untuk mempertahankan usaha yang dijalankan. Seorang wirausaha juga harus mampu mengelola usaha, dana, dan sumber daya secara baik (Sulastri, 2017).

Ciri-ciri seorang wirausaha adalah memiliki motivasi untuk berprestasi, berdaya cipta tinggi, selalu perspektif, inovatif, memiliki rasa tanggung jawab dan etos kerja, berkomitmen, berani mengambil resiko, mandiri, memiliki jiwa kepemimpinan, selalu mencari peluang, memiliki kemampuan personal, dan memiliki kemampuan manajerial (Suharyono, 2017).

Fontana (2009) menjelaskan bahwa seorang entrepreneur atau wirausahawan banyak memiliki karakteristik dan cara dalam menjalankan sebuah usaha yang di dalamnya adalah pencarian peluang, penciptaan produk atas dasar pengalaman selama periode waktu tertentu, pengetahuan yang diperoleh secara sengaja atau tidak sengaja, namun sebagian juga melakukannya secara sengaja atau dengan perencanaan. Sehingga para pengusaha tersebut menjadi sukses secara ekonomi dan sosial.

Faktor-faktor yang mempengaruhi keberhasilan usaha perlu diketahui. Sulistyowati dan Nining (2016), menjelaskan bahwa pertumbuhan usaha masih menjadi masalah yang dihadapi oleh usaha kecil menengah. Hal tersebut dipengaruhi oleh kurangnya nilai kewirausahaan, pembiayaan, serta pasar, serta faktor eksternal lainnya.

\section{METODE PENELITIAN}

Penelitian ini merupakan penelitian studi literatur. Desain penelitian yang digunakan dalam penelitian ini adalah systematic review, yang bertujuan untuk lebih memudahkan dalam identifikasi pertanyaan dalam melakukan penelitian 
(research question) hingga mendapat kesimpulam dari mensitesis hasil-hasil kajian sebelumnya.

Sumber informasi dan data dari penelitian ini adalah jurnal-jurnal terkait yang membahas tentang kegiatan berwirausaha di bidang agribisnis atau entrepreneur agribisnis yang telah dilakukan individu maupun kelompok yang berhasil di dalam melakukan kegiatan usaha.

\section{HASIL DAN PEMBAHASAN}

Seorang wirausaha sekurangkurangnya memiliki 12 karakteristik, yaitu: (1) motif berprestasi, (2) selalu perspektif, (3) berdaya cipta tinggi, (4) memiliki perilaku inovatif tinggi, (5) memiliki komitmen dalam pekerjaan, (6) memiliki etos kerja dan tanggung jawab, (7) mandiri atau tidak tergantung pada orang lain, (8) berani menghadapi resiko, (9) selalu mencari peluang, (10) memiliki jiwa kepemimpinan, (11) memiliki kemampuan manajerial dan (12) memiliki kemampuan personal (Suharyono, 2017).

\section{Inovasi}

Inovasi adalah salah satu faktor yang yang mendasar dan tergolong kedalam budaya individu ataupun organisasi adalah salah satu modal yang tak berwujud (intangible) untuk suatu perusahaan.
Menurut Schein (2010), budaya ini atau inovasi adalah unsur pendorong di dalam diri seorang pengusaha yang tidak terlihat, yang berkaitan dengan asas tertentu yaitu norma, pengetahuan, kepercayaan serta nilai bersama yang dimiliki oleh individua atau organisasi tersebut.

Sedangkan Komisi Eropa (2010) memaparkan bahwa aspek inovasi dalam agribisnis dapat dibedakan atau dikelompokan ke dalam lima bidang, yaitu: (1) aspek pertama dalam inovasi agribisnis ini adalah inovasi produk atau kegiatan onfarm, di dalam aspek ini menitikberatkan kepada peningkatan kualitas produk dalam proses produksi yang baik dan benar, sesuai dengan standard operational procedur (SOP). Dewasa ini banyak sekali informasi yang dapat diakses untuk meningkatkan inovasi sesuai dengan kebutuhan pasar, apa yang diminati pasar, dan yang dibutuhkan oleh pasar. (2) aspek kedua adalah menyangkut kedalam proses inovasi penerapan teknik baru dalam kegiatan produksi yang melibatkan teknologi tertentu. Salah satunya hidroponik dengan menggunakan Nutrient film technique sehingga lebih efisien. (3) aspek ketiga adalah pemasaran produk yang inovatif, karena teknologi semakin canggih dan membuat proses pemasaran lebih mudah, misalnya peranan 
media sosial untuk sekarang ini sangat efektif dimana sosial media menjadi sudah menjadi sesuatu yang sangat dekat dengan masyarakat, khususnya masyarakat perkotaan. (4) aspek keempat adalah inovasi dalam organisasi usaha yang dijalankan, karena banyak sekali organisasi yang belum maksimal dalam menjalankan peranannya seperti gapoktan. Hal ini bisa menyokong atau membantu dalam hal menanggung risiko, berbagi peran, dan berbagi informasi diantara sesama pelaku usaha, sehingga usahatani khususnya dapat lebih mudah dilakukan. (5) aspek kelima adalah aspek inovasi yang bersifat ramah lingkungan atau eco-innovation dalam usaha yang dilakukan, khususnya dalam usahatani. Pemahaman tentang inovasi yang sustain ini bermanfaat untuk menjaga kesuburan lahan dalam usahatani agar usaha dapat berlangsung lebih lama di masa depan atau di masa yang akan datang.

\section{Pendidikan}

Pelaku usaha dengan tingkat pendidikan tinggi cenderung lebih memiliki sifat atau sikap inovatif untuk selalu belajar dan mencari informasiinformasi baru terkait dengan bidang usaha yang digeluti (Weir and Knight, 2004). Bagi sebagian pelaku usaha, pendidikan menjadi biaya tambahan dalam kegiatan usaha mereka khusunya dalam pengeluaran model bisnis (Kilpatrick, 2000).

\section{Perilaku Sukses}

Sudut pandang setiap orang dalam melihat sebuah kesuksesan berbeda-beda dan subjektif untuk setiap individu. Pertanyaan yang sering muncul atau sering ditanyakan terkait kesuksesan adalah terkait unsur apa saja yang membuat orang sukses dan bisa dikatakan berhasil. Apakah kesuksesan setiap pelaku usaha diperoleh dari keberuntungan yang melekat pada seorang individu, atau diperoleh dari kerja keras, keterampilan dan sikap mereka dalam memperoleh kesuksesan itu sendiri. Kertajaya (2008) dalam buku Marketing Plus 2000 menjelaskan bahwa keberuntungan bukanlah hal yang terencana, namun suatu hal yang dipersiapkan secara matang dan perencanaan yang sangat matang juga.

Perilaku sukses ini dipengaruhi oleh dua faktor atau dapat dilihat dari sisi internal (endogen) dan eksternal (eksogen) dari individu tersebut atau individu pelaku usaha. Penelitian yang dilakukan Mukti dkk. (2017) menunjukkan bahwa karakteristik endogen ini terkait dari sikap, keterampilan dan kemampuan, artinya bukan hanya dari aspek pendidikan yang mempengaruhi keberhasilan usaha. Namun, semangat menjalankan bisnis 
dengan sungguh-sungguh juga termasuk ke dalam keterampilan dan kemampuan yang harus dimiliki oleh pelaku usaha. Dan jika menyangkut ke dalam faktor atau karakteristik eksogen lebih melihat dari faktor di luar kemampuan, yaitu keberuntungan. Akan tetapi, untuk kebanyakan pelaku usaha kembali lagi kepada pelaku usaha itu sendiri, yaitu kemampuan, pengetahuan dan sikap pelaku usaha dalam melakukan usaha tersebut.

\section{KESIMPULAN}

Untuk memperoleh kesuksesan, setiap pelaku usaha memiliki caranya masing-masing, sesuai dengan kebiasaan atau perilakunya dalam menjalankan sebuah usaha, latar belakang pendidikan, budaya masyarakat secara umum. Budaya wirausaha tersebut tertunya memberikan pengaruh yang cukup signifikan terhadap pelaku pebisnis. Budaya ini memberikan gambaran perilaku individu dan juga organisasi dalam menjalankan aktivitas bisnisnya. Kesuksesan dalam kegiatan berwirausaha, baik itu dalam agribisnis maupun usaha lainnya, harus dijalankan secara konsisten, sungguh-sungguh, memahami keinginan pasar, memperkuat pengetahuan tentang manajemen usaha, selalu mengikuti perkembangan teknologi informasi, dan mampu beradaptasi dengan lingkungan yang dinamis.

\section{DAFTAR PUSTAKA}

Lestari, F. A. P. (2019). Faktor-faktor yang Mempengaruhi Keberhasilan Berwirausaha. Jurnal Riset Inspirasi Manajemen Dan Kewirausahaan, 3(2), 65-69.

Mukti, G.W., Kusumo, R.A.B. dan Qanti, S.R. (2017). Perilaku Sukses Petani Muda Wirausaha Lulusan Fakultas Pertanian Universitas Padjadjaran. Jurnal Agribisnis Terpadu, 10(2): 221-234.

Pamela, Rachmat, P., \& Ratna, W. (2016). Kompetensi Kewirausahaan dengan Keberhasilan Usaha Peternak Sapi Perah Pujon, Malang. Jurnal Agribisnis Indonesia, 4(1), 57-66. https://doi.org/10.29244/jai.2016.4.1. 57-66

Putra, B. P. (2018). Peningkatkan Jumlah Wirausahawan Di Indonesia Melalui Kolaborasi Akademisi - Pelaku Usaha - Mahasiswa. Economicus, 9(1), 63-71. https://doi.org/10.47860/economicus. v12i1.147

Suharyono. (2017). Sikap dan Perilaku Wirausahawan. Jurnal Ekonomi MODERNISASI, 40(56), 6551-6586.

Sulastri, S. (2017). Pengaruh Jiwa Kewirausahaan terhadap Keberhasilan Usaha Susu Kedelai di Kecamatan Braja Selebah Lampung Timur. Dinamika, 3(2), 37-44.

Sulistyowati, E., \& Nining, S.0 L. (2016). Faktor-faktor Penentu Keberhasilan Usaha Kecil dan Menengah (UKM) di Kota Yogyakarta. Jurnal Maksipreneur: Manajemen, Koperasi, Dan Entrepreneurship, 6(1), 24-46. https://doi.org/10.30588/jmp.v6i1.28 2 